\title{
TERRITÓRIOS DE CUIDADO: REFLEXÕES SOBRE A ÉTICA E A PRÁTICA DO CUIDADO NA VELHICE.
} TERRITORIES OF CARE: REFLECTIONS ON THE ETHICS AND PRACTICE OF CARE IN OLD AGE.

TERRITOIRES DE SOIN: RÉFLEXIONS SUR L'ÉTHIQUE ET LA PRATIQUE DU SOIN CHEZ LES PERSONNES ÂGÉES.

EL TERRITORIO DE LOS CUIDADOS: REFLEXIONES SOBRE LA ÉTICA Y LA PRÁCTICA DE LOS CUIDADOS EN LA VEJEZ.

\author{
Marcia Regina Medeiros Veiga* \\ iD : http://orcid.org/0000-0003-2222-1958
}

RESUMO: A partir de um estudo etnográfico desenvolvido em Coimbra, Portugal, durante os anos 2013 a 2017, que teve como sujeitos as relações estabelecidas entre pessoas idosas e seus territórios de vivência e maior permanência e frequência, este artigo propõe uma reflexão acerca do cuidado. Historicamente, o cuidado tem pontuado relações fortemente hierárquicas, envolvendo vulnerabilidades e desigualdades sociais, econômicas, etárias e de gênero. Esta hierarquização tende a fragilizar os sujeitos que, dependendo da relação estabelecida, encontram-se na posição de quem é cuidado ou, inversamente, de quem cuida. Por outro lado, as abordagens acadêmicas a respeito do cuidado têm privilegiado as questões relativas ao trabalho, nomeadamente ao trabalho doméstico e à prestação de serviços educativos, de saúde ou estéticos. As reflexões aqui sugeridas pretendem aprofundar a temática do cuidado enquanto ethos e práxis possíveis e necessárias, que atravessam as relações sociais e que tenham como ponto originário, dialético e de encontro os territórios de proximidade.

Palavras-chave: cuidado; ética; política; velhices; territórios

\footnotetext{
* Doutora em Estudos Contemporâneos; Professora da Rede Municipal de Ensino de Santa Maria, RS; Técnica em Assuntos Educacionais da Universidade Federal de Santa Maria (UFSM), Santa Maria, RS, Brasil; e-mail: marciarmveiga@gmail.com
} 
ABSTRACT: This article proposes a reflection on care based on an ethnographic study carried out in Coímbra, Portugal, between 2013 and 2017, which addressed the relationships established between the elderly and the territory where they live, where they spend most of their time and experienced the most. Over time, care for the elderly has been characterised by strong hierarchical relationships that implied vulnerabilities and social, economic, age and gender inequalities. This hierarchy tends to undermine the people who, depending on the relationship established, either give or receive the care. Moreover, academic approaches to care have given priority to questions related to work - more specifically, domestic workand the provision of educational, health or aesthetic services. The thoughts we put forward here aim to deepen the topic of care as possible and necessary ethos and praxis that go beyond social relationships and that have the territory of proximity as the original, dialectic and meeting point.

Keywords: care; ethics; policies; old age; territory.

RÉSUMÉ: À partir d'une étude ethnographique développée à Coimbra, au Portugal, entre 2013 et 2017, qui a eu pour thèmes les relations établies entre les personnes âgées et leurs territoires de vie et de plus grandes permanence et fréquence, cet article propose une réflexion sur les soins. Historiquement, les soins ponctuent des relations fortement hiérarchiques, impliquant des vulnérabilités et des inégalités sociales, économiques, d'âge et de genre. Cette hiérarchisation tend à fragiliser les individus qui, selon la relation établie, sont dans la position de celui qui est soigné ou, à l'inverse, de celui qui soigne. D'autre part, les approches universitaires en matière de soins se sont concentrées sur des questions liées au travail, notamment au travail domestique et à la prestation de services éducatifs, sanitaires ou esthétiques. Les réflexions suggérées ici cherchent à approfondir le thème des soins en tant qu'éthos et praxis possibles et nécessaires, qui traversent les relations sociales et ont les territoires de proximité pour point d'origine, dialectique et de rencontre.

Mots-clés: soins; éthique; politique; vieillesses; territoires.

RESUMEN: Este artículo propone una reflexión acerca de los cuidados a partir de un estudio etnográfico realizado en Coímbra, Portugal, entre los años 2013 y 2017, que tuvo como objeto las relaciones establecidas entre las personas de la tercera edad y el territorio en donde vivieron, en el que más tiempo pasaron y que más frecuentaron. Históricamente, los cuidados se han caracterizado por unas relaciones muy jerárquicas que implicaban vulnerabilida- 
des y desigualdades sociales, económicas, etarias y de género. Esta jerarquización tiende a debilitar a las personas que, dependiendo de la relación que se haya establecido, dan o reciben los cuidados. Por otra parte, los abordajes académicos sobre los cuidados han dado prioridad a las preguntas relativas al trabajo - y más concretamente, al trabajo doméstico-y a la prestación de servicios educativos, de salud o estéticos. Las reflexiones que aqui sugerimos pretenden profundizar en el tema de los cuidados en cuanto ethos y praxis posibles y necesarias que vayan más allá de las relaciones sociales y tengan como punto de partida original, dialéctico y de encuentro el territorio de proximidad.

Palabras clave: cuidados; ética; política; vejez; territorio.

\section{INTRODUÇÃO}

Identificar as influências mútuas que as pessoas idosas e seus territórios de proximidade - os territórios onde vivem, onde constroem seus laços, seus cotidianos, suas identidades - exercem para a gestão e a vivência tanto das velhices, quanto dos próprios territórios, a partir das relações por e entre eles estabelecidas e experienciadas e tendo como lentes investigativas as acessibilidades dos territórios e as mobilidades e sociabilidades dessas pessoas, foi o objetivo central de um estudo etnográfico desenvolvido na cidade de Coimbra, Portugal, durante os anos de 2013 a 2017 (Veiga, 2017).

O estudo, que contou com a participação de 42 pessoas idosas, mulheres e homens, com idades entre os 65 e os 96 anos, foi realizado em quatro diferentes microterritórios da cidade de Coimbra, Portugal, dois urbanos (a Alta histórica e o bairro da Solum) e dois rurais (o Botão e o Casal do Lobo).

A premissa de que os territórios - e aqui é importante destacar minha compreensão de território enquanto uma categoria complexa, que envolve dimensões que vão além da geografia física ${ }^{1}$ - participam dos cotidianos das pessoas de modo a influenciá-los, tanto positiva quanto negativamente, foi confirmada durante minhas

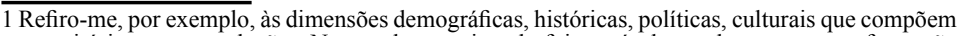
um território em suas relações. No estudo mencionado foi possível perceber o quanto a formação histórica e a estrutura de cada território (sua população, sua organização, as relações ali desenvolvidas) influenciam diretamente nas vivências cotidianas. 
incursões pelos territórios e interações com as pessoas idosas que participaram do estudo.

Ao longo de todo o percurso investigativo, o cuidado se impôs enquanto elemento essencial para a qualificação dos territórios - em todas as suas dimensões, mas, de forma destacada, em sua dimensão social e relacional - e, em consequência, das experiências de velhice. Esta imposição, observada principalmente a partir de territórios descuidados e hostis ${ }^{2}$ - especialmente às pessoas idosas e/ou com mobilidade reduzida -, possibilitou a proposição do que tenho chamado de territórios de cuidado, isso é, territórios que têm o cuidado como princípio ético e prático em todas as suas relações.

Neste artigo, começo por uma contextualização teórica a respeito de minha percepção a respeito de cuidado. Em seguida, passo para uma breve descrição de meu suporte empírico para, no final do texto, apresentar minhas considerações sobre a temática a partir dos territórios estudados.

\section{CUIDADO: UM CONCEITO ÉTICO E POLÍTICO}

Falar de cuidado desde uma dimensão ética é falar de política, no sentido amplo que este termo comporta, enquanto um movimento livre e espontâneo, expresso na pluralidade humana e estabelecido como relação (Arendt, 2018 [1950]), ou seja, como a própria vida social, que é relacional e dinâmica (Sodré, 1998). Em outras palavras, o cuidado é compreendido aqui como um princípio sustentado na alteridade, que "diz respeito a uma ética da vida, da preservação" (Carvalho; Maia, 2009, p. 19), e como uma política "exercida no cotidiano da práxis" (Carvalho; Maia, 2009: 20). Nesse contexto, o cuidado opõe-se ao descuido, ao descaso, ao individualismo e ao egocentrismo. "Representa uma atitude de ocupação, preocupação, de responsabilização e de envolvimento afetivo [e efetivo] com o

\footnotetext{
2 Refiro-me a territórios como a Alta de Coimbra, por exemplo, com sua tipologia física acompanhando sua geografia íngreme, com acessos dificultados, principalmente à população com pouca mobilidade; sua população idosa vivendo, em sua maioria, de forma isolada, dependendo de voluntariado e de instituições assistenciais; com pouca oferta de serviços de transporte e de estabelecimentos comerciais voltados para a população residente, com ênfase muito grande ao turismo e à população flutuante de estudantes.
} 
Territórios de cuidado: reflexões sobre a ética e a prática do cuidado na velhice.

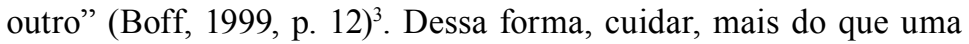
atitude meramente social, corresponde a uma atitude comunitária.

Enquanto um paradigma moral e ético, o cuidado é uma forma de estar no mundo, um "modo-de-ser essencial" (Boff, 1999, p. 13 - grifos do autor), que pressupõe que todos somos, na medida de nossa interdependência natural e saudável, seres de cuidado: necessitamos de cuidado e, ao mesmo tempo, somos cuidadores, provedores de cuidado; damos e recebemos cuidado, em um movimento contínuo e recíproco, que implica reconhecimento, aceitação e respeito pelas diferenças, pelas escolhas, pelas singularidades e pelas subjetividades de cada ser humano. Esta é uma dimensão importante do cuidado, pois exige um esforço em pensarmo-nos a partir de nossa igualdade e horizontalidade, sem, no entanto, ignorarmos nossas diferenças, transgredindo e superando padrões e preconceitos que tendem a direcionar de forma desigual e hierárquica os vetores do cuidado a partir de uma verticalização de cima para baixo: dos menos aos mais vulneráveis; dos mais ricos aos mais pobres; dos saudáveis aos doentes; dos mais jovens aos mais velhos ${ }^{4}$; e, ainda, como uma prática eminentemente feminina, o que, historicamente, tem sobrecarregado as mulheres e cristalizado discriminações, preconceitos e intolerâncias em relação aos sexos e gêneros ${ }^{5}$.

Em relação a este último ponto, é importante referir o trabalho da filósofa e psicanalista feminista estadunidense Carol Gilligan, uma das primeiras a teorizar sobre o cuidado nos meios acadêmicos. Contrapondo-se ao seu conterrâneo e também psicanalista Lawrence Kohlberg, para quem o desenvolvimento da moral se daria sobre princípios abstratos, a partir de uma ética da justiça, centrada na

3 Em suas reflexões sobre cuidado, Boff toma como referência o filósofo Martin Heidegger, para quem o cuidado tem uma dimensão ontológica, ou seja, faz parte da constituição humana (Boff, $1999 ; 2005)$. É de Heidegger (1989, p. 265) a seguinte afirmação: "O cuidado subministra preliminarmente o solo em que toda a interpretação do ser humano se move".

4 Dessa forma, o cuidado acaba sendo confundido com caridade, prática que, segundo Galeano, é muito diferente da solidariedade e, portanto, do cuidado: "Ao fim e ao cabo, a caridade consola, mas não questiona. [...] Diferente da solidariedade, que é horizontal e se exerce de igual para igual, a caridade se pratica de cima para baixo, humilha quem recebe e jamais altera, nem um pouquinho, as relações de poder: na melhor das hipóteses, em algumas vezes haverá justiça, mas no alto céu. Aqui na terra, a caridade não perturba a injustiça. Somente se propõe a dissimulá-la" (Galeano, 2004, p. 319-320).

5 "Cuidar do outro animus-anima [animus - dimensão masculina; anima - dimensão feminina] implica um esforço ingente de superar a dominação dos sexos [...]. Exige inventar relações que propiciem a manifestação das diferenças não mais entendidas como desigualdades, mas como riqueza da única e complexa substância humana" (Boff, 1999, p. 75). 
igualdade, na imparcialidade, nos direitos individuais e em escolhas racionais, Gilligan desenvolveu uma teoria do desenvolvimento da moral a partir do cuidado, das relações entre os sujeitos baseadas no compromisso, nas emoções, na empatia, na compaixão e no amor.

A crítica de Gilligan dirigia-se, sobretudo, à não existência de meninas nas pesquisas de Kohlberg - "os seis estágios de desenvolvimento do julgamento moral desde a infância até a idade adulta, descritos por Kohlberg, são empiricamente baseados em um estudo com oitenta e quatro meninos, cujo desenvolvimento foi acompanhado por Kohlberg por mais de vinte anos"6 (Gilligan, 1993, p. 18 - tradução livre) -, o que acabava por reforçar uma epistemologia hegemônica masculina. Além disso, a análise de Kohlberg sugeria a superioridade de atributos ditos masculinos - imparcialidade, racionalidade, individualismo, por exemplo - sobre atributos ditos femininos - como bondade e sensibilidade às necessidades de outrem.

Ao questionar as pesquisas e interpretações de Kohlberg que, em verdade, legitimavam uma ciência e uma sociedade andróginas - Gilligan tocou em um ponto essencial das desigualdades sociais: as diferenças entre os gêneros. Sua reflexão e o desejo de fazer ouvir uma "voz diferente" (Gilligan, 1993), trazendo à tona uma voz feminina, entretanto, foram entendidos, por parte de algumas/alguns feministas, como essencialistas e a-históricos. Joan Scott (1995), por exemplo, teceu severas críticas a respeito do trabalho de Gilligan:

Gilligan explica os diferentes modos de desenvolvimento moral dos meninos e das meninas, em termos de "experiências" (de realidade vivida). Não é surpreendente que os(as) historiadores(s) das mulheres tenham retomado suas ideias e as tenham utilizado para explicar as "vozes diferentes" que o seu trabalho lhes havia permitido ouvir. Os problemas com esses empréstimos são diversos e logicamente conectados. O primeiro problema que esse tipo de empréstimo coloca é um deslizamento que acontece frequentemente na atribuição de causalidade: a argumentação começa com a afirmação do tipo "a experiência das mulheres levam-nas a fazer escolhas morais que dependem dos contextos e das relações", para chegar à: "as mulhe-

6 Do original: "Kohlberg's six stages that describes the development of moral judgment from childhood and adulthood are based empirically on a study of eighty-four boys whose development Kohlberg has followed for a period of over twenty years". 
Territórios de cuidado: reflexões sobre a ética e a prática do cuidado na velhice.

res pensam e escolhem esse caminho porque elas são mulheres". Encontramos implicadas nessa abordagem a noção a-histórica, se não essencialista, de mulheres. (Scott, 1995, p. 86-87)

De fato, por esta interpretação, Gilligan entenderia o cuidado como uma disposição eminentemente feminina e, por isso, naturalmente atribuída às mulheres. Por esta visão, o trabalho de Gilligan só reforçaria os estereótipos a respeito das diferenciações de gênero baseadas unicamente nas diferenças entre os sexos e, ainda, legitimaria uma postura machista e hierárquica em relação ao cuidado.

Uma outra interpretação, no entanto, com a qual prefiro me identificar, também é possível: Gilligan referiu a uma diferença entre os desenvolvimentos morais masculinos e femininos, compreendendo masculino e feminino como princípios inerentes a todos os seres humanos e não necessariamente associados, especificamente, aos homens (no caso do masculino) e às mulheres (no caso do feminino) ${ }^{7}$. As reflexões de Muraro (2007, p. 19) concordam com este argumento, já que "[t]odos nós temos um feminino e masculino dentro de nós [...]. Eles estão mais dentro do inconsciente que do consciente. No nosso consciente, o que encontramos são muitos preconceitos, padrões, estereótipos, construídos durante milênios pela sociedade inteira para separar o feminino do masculino". Essa separação entre os dois elementos constitutivos dos seres humanos é um reflexo do patriarcado, sistema de relações sobre o qual a maioria das sociedades está estruturada e que tem o poder político expresso na dominação/exploração masculina (Muraro, 2007; Saffioti, 2007; Kuhnen, 2014; 2014b; Palacio, 2015). Por esta interpretação, o cuidado é uma teoria política, uma proposta paradigmática de compreensão e de vivência igualitária em sociedade. Assim, "[um] olhar igualitário nos permitiria compreender que tanto as dinâmicas geradas pelos meninos, quanto pelas meninas são necessárias ao exercício do ser social que identifica as pessoas" (Pérez, 2011, p. 04).

7 "O feminino no homem e na mulher é um dos princípios que originam em nós a percepção da totalidade, permitindo-nos ver símbolos nas coisas, e ritos nos atos, fazendo-nos cultivar o espaço do mistério do mundo, inclinando-nos ao enternecimento e ao cuidado, tornando-nos mais cooperadores que competitivos. O regate da anima (feminino) é fundamental para colocar a vida no centro de tudo e para fundar uma relação não utilitarista, mas afetuosa com a realidade envolvente" (Barbosa, 2009, p. 117 - grifos do autor). 
Partindo das reflexões e teorizações de Gilligan, porém aprofundando-as, problematizando-as, politizando-as e tornando-as mais abrangentes, Fisher e Tronto formularam um conceito de cuidado que o coloca como "uma atividade da própria espécie que inclui tudo o que podemos fazer para manter, continuar e reparar nosso 'mundo' para que possamos viver nele da melhor maneira possível"» (Fisher; Tronto, 1990, p. 40 - tradução livre).

Quando definimos cuidado dessa forma, nossa visão de mundo se transforma. De repente, nós não apenas vemos que o mundo é constituído de indivíduos autônomos que perseguem fins racionais e projetos de vida, mas vemos também que ele é feito de pessoas emaranhadas em redes de interesse e comprometidas com o atendimento das necessidades de outras pessoas ao seu redor. Isso não significa dizer que cada atividade do mundo refere-se ao cuidado, mas muitas o são. E essas atividades podem estar "aninhadas" no sentido de que elas são perseguidas porque podem contribuir para que outros objetivos sejam alcançados (Tronto, 2007, p. 289).

Tronto (2009, p. 17) enfatiza o cuidado como um valor democrático, compreendendo a democracia como a única estrutura capaz de permitir a elaboração de uma teoria do cuidado adequada ao mundo contemporâneo. Entretanto, para que, efetivamente, este valor possa ser exercido como tal, é necessário que haja o reconhecimento consciente da vulnerabilidade e da dependência como intrínsecas a todos os seres humanos. Nesse sentido, os sujeitos são concebidos como seres relacionais, dependentes de vínculos sociais (Pereira, 2011).

Por outro lado, o cuidado deve ser uma ética e uma práxis de fluxo contínuo e circular, não uma dicotomia entre quem cuida e quem é cuidado/a. Além disso, o cuidado deve ser facultado a todas as pessoas como um direito universal sem que, no entanto, as singularidades e diferenças sejam desconsideradas (Mozère, 2009; Tronto, 2009). Assim, igualdade e reconhecimento, no sentido atribuído por Fraser (2006; 2007), como uma abertura às diferenças a partir da desinstitucionalização de valores que impedem a paridade

8 Do original: "One the most general level, we suggest that caring be viewed as a species activity that includes everything that we do to maintain, continue, and repair our 'world' so that we can live in it as well as possible". 
Territórios de cuidado: reflexões sobre a ética e a prática do cuidado na velhice.

na participação social, são premissas para uma ética do cuidado (Szpacenkopf, 2009).

A proposta de Tronto avança, buscando a superação da dimensão do cuidado enquanto uma atividade e/ou profissão assimétrica (em sentido duplo: superioridade de quem cuida, a partir de uma relação de caridade e assistencialismo ou, em sentido inverso, superioridade de quem é cuidado/a, no sentido de que quem presta este cuidado está, de alguma forma, subordinado/a àquela pessoa), assumindo uma dimensão política em que a atenção, a responsabilidade, a competência e a capacidade de responder às necessidades de si próprio/a, das outras pessoas e do meio ambiente são disposições inerentes a todos os seres humanos, sendo necessárias a uma convivência social mais equilibrada (Tronto, 2007; 2009; Mozère, 2009).

Reconhecer o valor do cuidado remete à questão da estrutura de valores de nossa sociedade. O cuidado não é uma preocupação localizada das mulheres, um tipo de questão secundária ou o trabalho de membros menos favorecidos da sociedade. O cuidado é um elemento essencial da vida humana. É hora de começar a transformar nossas instituições políticas e sociais de modo que estas passem a refletir esta realidade9 (Tronto, 2009, p. 232 - tradução livre).

Dessa forma, o cuidado, como um conceito político, evoca direitos e responsabilidades e deve ser vivenciado cotidianamente nas relações entre homens e mulheres; crianças, jovens, adultos/as e idosos/as; pessoas de todas as etnias, culturas, e extratos sociais.

Sendo um conceito político, o cuidado, enquanto uma ética e uma práxis, não deve - e não pode - desresponsabilizar as instâncias estruturais e institucionais da esfera política, principalmente pública. Ao contrário, "[u]ma ética do cuidado pode dar um novo ponto de partida ao papel do Estado em relação às verdadeiras prioridades políticas de sociedades em que a pessoa humana deve ser o centro e o fim último de toda a decisão política" (Pintasilgo, 2012, p. 138).

Uma abordagem ética e política de cuidado - marcadamente

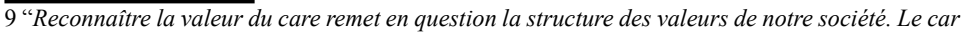
ene constitue pas une préoccupation localisée des femmes, un type de question morale secondaire, on le travail des membres les moins favorisés de la societé. Le care est un élément essentiel de la vie humaine. Il est temps pour nous de commencer à transformer nos institutions politiques et sociales pour qu'elles reflètent cette réalité" (texto original). 
quando temos como sujeitos as pessoas idosas -, requer que repensemos conceitos-chave, como autonomia e dependência. A autonomia pode ser conceituada como um direito de escolha, de decisão, tanto a nível individual, ou seja, referente a escolhas e decisões pessoais, quanto coletivo, isso é, como resultados de processos de interação (Simões et al., 2010). Em ambos os níveis, a autonomia requer comprometimento e responsabilidade. Por isso mesmo, Freire (1997, p. 67) a compreende como um processo, um "vir a ser", que deve ser trabalhado e amadurecido no âmbito de seu exercício.

Nunes (2016, p. 14-15) trabalha o conceito de autonomia como um exercício diretamente atrelado ao poder: "Porque a vontade pessoal tem a ver com potência. Uma das capacidades de uma pessoa adulta e na posse de suas faculdades mentais é a de decidir sobre si mesma - e aos outros, quaisquer outros, mesmo que os tenhamos ouvido e incluído no processo, cabe respeitar a decisão que tomamos". Assim, o exercício autônomo é, de uma certa forma, um exercício impositivo entre o individual e o social, onde está em jogo a manifestação - e imposição - de uma vontade individual que deve receber como resposta o respeito dos demais membros do grupo social.

As questões relativas à liberdade e ao esclarecimento comumente são associadas à autonomia enquanto "exercício de uma 'vontade livre e esclarecida"” (Nunes, 2016, p. 15).

Considerando a liberdade como um princípio circunstancial, ou seja, dependente de circunstâncias e contextos próprios, quer sejam individuais, quer sejam sociais, as escolhas são livres na medida das possibilidades desses contextos e dessas circunstâncias. Da mesma forma, só há esclarecimento quando se conhece, prévia e minimamente, as implicações às quais cada opção de escolha pode conduzir, "[p]ois nem sempre aos atos se seguem as consequências previsíveis, possíveis, prováveis. Também acontecem consequências improváveis, imprevistas e, até, adversas" (Nunes, 2016, p. 16). Estas observações e ponderações reforçam a necessidade de se tomar a autonomia como um processo entre indivíduos e comunidades que deve ser constantemente exercitado, praticado e (re)elaborado (Freire, 1997). 
O respeito às decisões pessoais que não afetam negativamente a comunidade, de um modo geral, e as pessoas que dela participam, em particular, é um preceito que, necessariamente, deve ser seguido, até porque, como já foi mencionado, a autonomia deve ser considerada como um direito. Outro ponto importante diz respeito à acessibilidade como condicionante da autonomia:

Se os ambientes são concebidos só para "alguns", grande parte sentirá a hostilidade dos espaços ou mesmo a impossibilidade de os utilizar. Privar a pessoa de agir livremente consoante as suas motivações, escolhas e ações é agir em desacordo com o princípio do respeito pelo outro, pela vida individual e pela vida social (Simões et al., 2010, p. 05).

Por seu turno, a palavra independência é usualmente tomada como sinônimo de autonomia. Entretanto, se analisarmos o seu antônimo - dependência - em termos de reciprocidade, horizontalidade e condição própria dos seres humanos e sociais como interdependentes - dependentes entre si -, o peso negativo desta palavra se esvazia, perdendo grande parte de seu sentido usual. "A interdependência reforça a sobrevivência de todos, pois todos se entreajudam. Essa sinergia e essa cooperação constituem a chave para compreender a sobrevivência e a biodiversidade, e não simplesmente a força do indivíduo que se impõe aos demais" (Boff, 2006, p. 47).

Tronto (2009, p. 212) analisa o imperativo da independência como uma imposição do pensamento político e moral de inspiração liberal, que, em sua origem, buscou quebrar as formas de dependência descritas nas sociedades medievais e em outras organizações sociais pré-liberais. As concepções liberais de autonomia, portanto, rejeitam a dependência, compreendendo-a como uma destruição da personalidade. Entretanto, a interdependência, como um princípio humano e político, vê essa imposição como um princípio egocêntrico e, como tal, prejudicial a uma vivência social harmônica, equilibrada e humana. Esta nova concepção de (inter)dependência equaliza e desierarquiza as relações, uma vez que todos/as, de uma forma ou de outra, dependemos uns/umas dos/as outros/as. 
Nesse sentido, autonomia e dependência não se opõem ou se contradizem, necessariamente. Pode-se ser autônomo/a, senhor/a de escolhas próprias e, ao mesmo tempo, dependente. Quando as reflexões, como as aqui propostas, giram em torno de relações sociais - e, como neste caso, quando se tem pessoas idosas como um dos sujeitos dessas relações - é importante e necessário que se dissocie a dependência da autonomia, desmistificando e desnaturalizando a noção de dependência e desconstruindo, por essa via, as relações de poder alicerçadas no binômio independência-dependência. Neste caso, o oposto à autonomia não é a dependência, mas a heteronomia (Zatti, 2007), a sujeição passiva a decisões, escolhas e normas de outrem.

Conceber o cuidado como um paradigma ético e como uma atitude política é, dessa forma, questionar, por exemplo, a institucionalização da velhice e, da mesma maneira, do próprio cuidado, como uma forma de descompromisso e desresponsabilização social - à qual Tronto (2007, p. 292) chama de "irresponsabilidade privilegiada". Também é acreditar na possibilidade de transformação do social a partir da humanização das relações, em um movimento que busca o estremecimento de estruturas sociais, políticas e econômicas - consolidadas através da imposição e da verticalização do poder (principalmente econômico) -, a partir de uma prática cotidiana comunitária e humana. É um movimento lento, que requer perseverança, e onde os territórios, principalmente o envolvimento e a articulação de comunidades mais próximas - a casa, a rua, o bairro -, têm um peso e uma força muito grandes, mas, em grande medida, ainda menosprezadas/os ou desconhecidas/os.

\section{VELHICES E TERRITÓRIOS - O REFERENCIAL EMPÍRICO}

No intuito de perceber a importância dos territórios de proximidade para as experiências de velhice, desenvolvi, durante os anos de 2013 a 2017, um estudo etnográfico que contou com a participação de 42 pessoas idosas, homens e mulheres, com idades entre 65 e 96 anos, residentes em um dos quatro microterritórios escolhidos para a investigação, todos localizados no município de Coimbra, Portugal. 
Coimbra é um município centro-litorâneo cuja história, que foi se desenhando a partir de suas configurações geográficas naturais, se confunde com a própria história de Portugal. Tendo sua origem no topo de uma colina - e, por isso mesmo, sendo identificada como uma das representantes das chamadas "cidades de colina", expressão "de acepção luso-brasileira associada à tradição urbanística de se escolherem sítios elevados para a fundação das urbes" (Lobo; Simões Júnior, 2012, p. 17) -, Coimbra vivenciou vários períodos históricos, sendo, ao longo dos séculos, dominada pelos romanos, invadida pelos bárbaros, tomada pelos muçulmanos e reconquistada pelos cristãos. Cada período histórico vivenciado pela cidade deixou grandes marcas, ainda hoje percebidas tanto em sua arquitetura, quanto na formação de seu povo e distribuição pelo território.

A importância política, estratégica, cultural e patrimonial de Coimbra para o contexto português e mundial se deve, em grande medida, à sua posição geográfica central em relação ao país e à sua geografia física, onde a colina - outrora ocupada pela realeza e, na atualidade, pelos prédios mais importantes da Universidade de Coimbra, a mais antiga universidade do país e uma das mais antigas do mundo - e o rio Mondego - que atravessa a cidade, dividindo-a em duas margens distintas -, tiveram um papel fundamental na defesa territorial e na delimitação hierárquica dos territórios.

Pois foram justamente as características geográficas de Coimbra, principalmente em sua Alta histórica, com trajetos difíceis de serem transpostos (ruelas íngremes, calçadas com pedras roliças e escorregadias), aliadas a uma população que, se não chega a ser a mais envelhecida do país, ainda assim chama a atenção pelo grande número de pessoas idosas, com um índice de envelhecimento superior ao português ${ }^{10}$, que atraíram meu olhar investigativo para essa cidade.

Sendo uma cidade universitária, Coimbra abriga, ainda, uma população jovem e transitória: estudantes oriundos/as de outras localidades do país e mesmo do mundo, que permanecem na cidade durante seus percursos acadêmicos, retornando aos seus territórios $10 \mathrm{O}$ Índice de Envelhecimento (IE) é calculado pelo número de pessoas com 65 ou mais anos para cada 100 pessoas com idades compreendidas entre 0 e 14 anos. Um valor superior a 100 indica que o número de idosos/as supera o número de jovens. De acordo com os últimos censos oficiais portugueses, realizados em 2011 pelo Instituto Nacional de Estatística português, o IE de Portugal era, àquele período, 127,8, enquanto o de Coimbra era 161,4. 
de origem - ou expandindo suas fronteiras para outros territórios - após sua conclusão. Outro ponto curioso é que Coimbra foi recentemente reconhecida pela União Europeia como a única cidade portuguesa referência para o envelhecimento ativo e saudável, não obstante as dificuldades impostas às pessoas idosas por algumas localidades bastante centrais desse território.

A questão principal que se colocou diante de mim foi a seguinte: em que medida os territórios influenciam - ou não - na(s) gestão(gestões) das velhices? Em outras palavras: pode-se dizer que as diferentes maneiras de envelhecer são, de certa forma, fruto das vivências das pessoas idosas nos/com os territórios? Buscando responder a estas questões, optei por desenvolver o estudo em quatro diferentes tipologias territoriais da cidade de Coimbra, duas urbanas e duas rurais. Os territórios urbanos escolhidos foram a Alta do centro histórico e o bairro da Solum; os rurais foram o Botão e o Casal do Lobo.

Apenas para caracterizar de maneira bastante breve cada um dos territórios, posso dizer que a Alta, localizada no centro histórico de Coimbra, é um território envelhecido, tanto em suas edificações - hoje ocupadas com os principais prédios da Universidade, com alojamentos estudantis, com moradias habitadas, majoritariamente, por pessoas idosas que vivem sós, e muitas adaptadas, num processo de gentrificação ${ }^{11}$, ao turismo -, quanto em sua população - composta, em grande parte, por idosos/as que dividem este espaço territorial com estudantes, cuja permanência quase sempre é transitória. As ruas estreitas, com calçamentos irregulares, insuficiência de transportes públicos e com raros espaços destinados ao trânsito pedestre caracterizam este território como pouco acessível, principalmente às pessoas idosas e demais pessoas com limitações motoras. A formação hierárquica deste território e as marcadas diferenças entre as duas principais populações que habitam a Alta - os/as jovens universitários/as e as pessoas idosas - têm representado um grande empecilho a uma convivência harmônica e de entreajuda, o que tem prejudicado e vulnerabi-

11 A gentrificação é um fenômeno fundamentalmente urbano que "consiste em uma série de melhorias físicas ou materiais e mudanças imateriais - econômicas, sociais e culturais - que ocorrem em alguns centros urbanos antigos, os quais experimentam uma apreciável elevação de seu status" (Bataller, 2012, p. 10 - grifos do autor). Esse fenômeno pode ter consequências bastante drásticas à população de um território que, no limite, pode ser, forçada a se deslocar para outro território, em razão de variadas dificuldades de manutenção e permanência no território original. 
lizado, de forma notória, a população idosa, que em parte significativa dos casos, precisa recorrer a apoios sociais e institucionais, como os Serviços de Apoio Domiciliários ${ }^{12}$, por exemplo.

O bairro da Solum, por sua vez, é uma nova centralidade projetada e construída a partir da segunda metade do século XX. Grande parte de sua edificação é constituída de altos prédios, a maioria com elevadores. É na Solum que se localiza um dos maiores shoppings centers da cidade, além de outros centros comerciais menores, mas não menos importantes para a configuração territorial, sendo, ainda, muito frequentados - tanto por moradores/as do bairro, quanto por pessoas de outras regiões da cidade - em suas lojas e cafés. Por ser um território plano, bem servido de transportes públicos, de calçadas para pedestres, de sinalização de trânsito, de serviços e de comércios, e possuindo, também, grandes áreas de convívio e lazer, a Solum pode ser considerada um território acessível.

Os dois territórios rurais, o Botão e o Casal do Lobo, estão localizados a poucos quilômetros do centro de Coimbra. No Botão, as habitações são mais antigas, geralmente possuindo um piso térreo - usado, no passado, para acomodar o gado e, dessa forma, aquecer as outras dependências da casa; atualmente este piso é utilizado como mais um cômodo da casa, geralmente a sala - e um segundo piso, ocupado com os dormitórios e o banheiro. A maior parte dos terrenos são planos e sem calçamento. O Casal do Lobo está localizado a leste da região central de Coimbra, em um espaço geográfico marcado pela altitude. As duas localidades possuem uma via principal asfaltada, com tráfego intenso de automóveis. Ambas têm a vida comunitária assentada na igreja. Devido à escassez de crianças em idade escolar, as escolas dos dois territórios foram desativadas, sendo, pouco a pouco, adaptadas para novos usos. Tal como o Botão, o Casal do Lobo é um território bastante antigo, em termos de ocupação. Entretanto, a maioria de seus prédios foi construída na década de 1980, resultado da melhoria das acessibilidades observada com a consolidação da demografia e como resultado da entrada de Portugal na, à época, designada 12 Os Serviços de Apoio Domiciliário (SAD) são realizados por Instituições Particulares de Solidariedade Social, instituições sem fins lucrativos que recebem aportes do estado. Nos SAD, uma equipe realiza a prestação de serviços (basicamente serviços de higiene pessoal e residencial e alimentação) no próprio domicílio do/a usuário/a em situação de dependência física e/ou psíquica temporária ou permanente. 
Comunidade Econômica Europeia - CEE - (hoje União Europeia UE), em 1986, o que propiciou, através dos fundos comunitários, a melhoria das condições da rede viária do país.

Durante o percurso investigativo, que durou quatro anos, visitei por várias vezes os quatro territórios, buscando apreender detalhes relativos às suas organizações, suas populações, suas arquiteturas, seus acessos, suas dinâmicas relacionais, bem como, a partir de consultas bibliográficas e a bases estatísticas e construção de mapas, suas formações históricas e geográficas. Também contei com a participação de 42 pessoas ( 30 mulheres e 12 homens), com idades entre os 65 e os 96 anos, com diferentes origens, constituições familiares, níveis de escolaridade/formação, ocupações, rotinas e expectativas futuras.

$\mathrm{Na}$ Alta, entrevistei onze mulheres e um homem ${ }^{13}$ com idades entre os 69 e os 92 anos, conforme o perfil que segue:

\begin{tabular}{|c|c|c|c|c|c|c|c|}
\hline NOME $^{14}$ & $\begin{array}{l}\text { IDA- } \\
\text { DE }\end{array}$ & SEXO & $\begin{array}{c}\text { EST. } \\
\text { CIVIL }\end{array}$ & $\begin{array}{l}\text { ESCOLA- } \\
\text { RIDADE }\end{array}$ & FILHOS & $\begin{array}{l}\text { CD/ } \\
\text { SAD }\end{array}$ & $\begin{array}{c}\text { COM } \\
\text { QUEM } \\
\text { VIVE }\end{array}$ \\
\hline Álvaro & 69 & $\begin{array}{l}\text { Ho- } \\
\text { mem }\end{array}$ & $\begin{array}{l}\text { Divor- } \\
\text { ciado }\end{array}$ & $\begin{array}{l}\text { Ensino Fun- } \\
\text { damental }\end{array}$ & 2 & CD15 & Só \\
\hline Adelaide & 74 & $\begin{array}{l}\text { Mu- } \\
\text { lher }\end{array}$ & Casada & $4^{\mathrm{a}}$ Série & Não & SAD & $\begin{array}{l}\text { Com o } \\
\text { marido }\end{array}$ \\
\hline Amália & 79 & $\begin{array}{l}\text { Mu- } \\
\text { lher }\end{array}$ & Solteira & $4^{\mathrm{a}}$ Série & Não & $\mathrm{CD}$ & Só \\
\hline $\begin{array}{c}\text { Apare- } \\
\text { cida }\end{array}$ & 79 & $\begin{array}{l}\text { Mu- } \\
\text { lher }\end{array}$ & Viúva & $4^{\mathrm{a}}$ Série & 1 & $\mathrm{CD}$ & Só \\
\hline Anita & 86 & $\begin{array}{l}\text { Mu- } \\
\text { lher }\end{array}$ & Viúva & $3^{\text {a }}$ Série & 3 & SAD & Só \\
\hline Amanda & 87 & $\begin{array}{l}\text { Mu- } \\
\text { lher }\end{array}$ & Viúva & $3^{a}$ Série & 1 & SAD & Só \\
\hline Angelita & 88 & $\begin{array}{l}\text { Mu- } \\
\text { lher }\end{array}$ & Viúva & $\begin{array}{l}\text { Ensino } \\
\text { Médio }\end{array}$ & 1 & $\mathrm{CD}$ & Só \\
\hline Adriana & 88 & $\begin{array}{l}\text { Mu- } \\
\text { lher }\end{array}$ & Casada & $6^{\text {a }}$ Série & Não & $\mathrm{CD}$ & $\begin{array}{l}\text { Com o } \\
\text { marido }\end{array}$ \\
\hline Aurora & 89 & $\begin{array}{l}\text { Mu- } \\
\text { lher }\end{array}$ & Solteira & Nenhuma & Não & SAD & Só \\
\hline
\end{tabular}

14 Para proteção de suas identidades, os nomes das pessoas que participaram da pesquisa foram substituídos por nomes fictícios.

15 Os CD (Centros de Dia) são definidos pelo Instituto da Segurança Social português como equipamentos sociais de funcionamento diurno que prestam vários serviços (higiene, alimentação, recreação, atividades de tempos livres) que ajudam a manter as pessoas idosas em seu meio social e familiar, uma vez que os/as usuários/as deslocam-se, geralmente pela parte da manhã, a estes Centros, retornando às suas casas ao final da tarde. 
Territórios de cuidado: reflexões sobre a ética e a prática do cuidado na velhice.

\begin{tabular}{cccccccc} 
Antónia & 89 & $\begin{array}{c}\text { Mu- } \\
\text { lher }\end{array}$ & Viúva & $4^{\text {a Série }}$ & 4 & SAD & $\begin{array}{c}\text { Com um } \\
\text { filho }\end{array}$ \\
\hline Augusta & 91 & $\begin{array}{l}\text { Mu- } \\
\text { lher }\end{array}$ & Solteira & Nenhuma & 1 & CD & Só \\
Agnes & 92 & $\begin{array}{l}\text { Mu- } \\
\text { lher }\end{array}$ & Viúva & $4^{\text {a Série }}$ & $\begin{array}{c}2 \text { (faleci- } \\
\text { dos) }\end{array}$ & CD & Só \\
\hline
\end{tabular}

Quadro 1: Perfil dos/as participantes da Alta.

A grande maioria das pessoas entrevistadas neste território vive só, afastada de familiares - quando estes existem -, em habitações envelhecidas e precárias - algumas sem saneamento básico -, geralmente alugadas, dependendo do apoio dos $\mathrm{CD}$ ou dos SAD para serviços básicos, como higiene pessoal e alimentação, com poucas oportunidades de uma interação social mais robusta e com fraca autonomia. São pessoas com baixos rendimentos e escolaridade, pouca mobilidade e participação social no território, contrastando com uma vizinhança jovem e flutuante, com altos níveis de escolaridade - os/as estudantes universitários/as.

Já na Solum, o outro território urbano do estudo, embora muitas das pessoas entrevistadas também vivam sós, pude perceber que a estrutura territorial possibilita uma maior mobilidade e autonomia dessas pessoas. Com condições sociais bem melhores, grande parte dos participantes deste território habita em residências próprias (em geral, apartamentos térreos ou localizados em prédios com elevadores). Os muitos espaços de convívio, estar e lazer (praças, parques, cafés, centros comerciais), frequentados, de uma forma geral, pelos/ as habitantes deste território, possibilitam contatos intergeracionais mais frequentes. Aqui, contei com a participação de dez pessoas (oito mulheres e dois homens) com idades entre os 76 e os 96 anos, conforme o quadro a seguir: 


\begin{tabular}{|c|c|c|c|c|c|c|c|}
\hline NOME & $\begin{array}{l}\text { IDA- } \\
\text { DE }\end{array}$ & SEXO & $\begin{array}{l}\text { EST. } \\
\text { CIVIL }\end{array}$ & $\begin{array}{c}\text { ESCOLARI- } \\
\text { DADE }\end{array}$ & $\begin{array}{c}\text { FI- } \\
\text { LHOS }\end{array}$ & $\begin{array}{l}\text { CD/ } \\
\text { SAD }\end{array}$ & $\begin{array}{c}\text { COM } \\
\text { QUEM VIVE }\end{array}$ \\
\hline Sara & 76 & $\begin{array}{l}\text { Mu- } \\
\text { lher }\end{array}$ & Viúva & Grad. em Física & 3 & - & Só \\
\hline Sílvia & 78 & $\begin{array}{l}\text { Mu- } \\
\text { lher }\end{array}$ & Casada & $4^{a}$ Série & 1 & CD & $\begin{array}{c}\text { Com o marido } \\
\text { e o filho }\end{array}$ \\
\hline Sérgio & 84 & $\begin{array}{l}\text { Ho- } \\
\text { mem }\end{array}$ & Casado & $4^{a}$ Série & 1 & $\mathrm{CD}$ & $\begin{array}{l}\text { Com a esposa } \\
\text { e o filho }\end{array}$ \\
\hline Susana & 84 & $\begin{array}{l}\text { Mu- } \\
\text { lher }\end{array}$ & Viúva & $4^{a}$ Série & 3 & CD & Só \\
\hline Soraia & 86 & $\begin{array}{l}\text { Mu- } \\
\text { lher }\end{array}$ & Viúva & $3^{\text {a }}$ Série & Não & $\mathrm{CD}$ & Só \\
\hline Simone & 86 & $\begin{array}{l}\text { Mu- } \\
\text { lher }\end{array}$ & Viúva & $\begin{array}{l}\text { Grad. em Far- } \\
\text { mácia }\end{array}$ & 1 & CD & Com o filho \\
\hline $\begin{array}{l}\text { Salva- } \\
\text { dor }\end{array}$ & 86 & $\begin{array}{l}\text { Ho- } \\
\text { mem }\end{array}$ & Viúvo & $4^{a}$ Série & 1 & CD & Com a filha \\
\hline Selma & 88 & $\begin{array}{l}\text { Mu- } \\
\text { lher }\end{array}$ & Viúva & $4^{a}$ Série & 2 & $\mathrm{CD}$ & $\begin{array}{l}\text { Com uma } \\
\text { filha e o genro }\end{array}$ \\
\hline Sueli & 90 & $\begin{array}{l}\text { Mu- } \\
\text { lher }\end{array}$ & Viúva & $\begin{array}{c}\text { Ensino Funda- } \\
\text { mental }\end{array}$ & Não & - & Só \\
\hline Solange & 96 & $\begin{array}{l}\text { Mu- } \\
\text { lher }\end{array}$ & Viúva & $4^{a}$ Série & 1 & $\mathrm{CD}$ & Só \\
\hline
\end{tabular}

Quadro 2: Perfil dos/as Participantes da Solum.

No Botão, participaram da pesquisa seis mulheres e quatro homens, dos 76 aos 93 anos, conforme mostra o quadro a seguir:

\begin{tabular}{|c|c|c|c|c|c|c|c|}
\hline NOME & $\begin{array}{c}\text { IDA- } \\
\text { DE }\end{array}$ & SEXO & $\begin{array}{c}\text { EST. } \\
\text { CIVIL }\end{array}$ & $\begin{array}{l}\text { ESCO- } \\
\text { LARIDA- } \\
\text { DE }\end{array}$ & $\begin{array}{c}\text { FI- } \\
\text { LHOS }\end{array}$ & $\begin{array}{l}\text { CD/ } \\
\text { SAD }\end{array}$ & $\begin{array}{c}\text { COM } \\
\text { QUEM VIVE }\end{array}$ \\
\hline Brenda & 76 & Mulher & Casada & $3^{\text {a }}$ Série & 2 & $\mathrm{CD}$ & Com o marido \\
\hline Bernardo & 79 & $\begin{array}{c}\text { Ho- } \\
\text { mem }\end{array}$ & Solteiro & $4^{\mathrm{a}}$ Série & Não & $\mathrm{CD}$ & $\begin{array}{l}\text { Com o cunhado e o } \\
\text { sobrinho }\end{array}$ \\
\hline Beatriz & 81 & Mulher & Viúva & Nenhuma & 2 & $\mathrm{CD}$ & Com uma filha \\
\hline Bonifácio & 81 & $\begin{array}{c}\text { Ho- } \\
\text { mem }\end{array}$ & Viúvo & Nenhuma & 7 & $\mathrm{CD}$ & $\begin{array}{l}\text { Com um filho, nora } \\
\text { e } 4 \text { netos }\end{array}$ \\
\hline Bruna & 83 & Mulher & Viúva & $3^{\text {a }}$ Série & 3 & $\mathrm{CD}$ & $\begin{array}{c}\text { Com a filha, genro e } \\
2 \text { netos }\end{array}$ \\
\hline Bárbara & 85 & Mulher & Viúva & $4^{\mathrm{a}}$ Série & 1 & $\mathrm{CD}$ & $\begin{array}{l}\text { Com a filha, genro } \\
\text { e } 1 \text { neto }\end{array}$ \\
\hline Benedita & 85 & Mulher & Viúva & $3^{a}$ Série & 1 & $\mathrm{CD}$ & Só \\
\hline Bento & 85 & $\begin{array}{l}\text { Ho- } \\
\text { mem }\end{array}$ & Viúvo & Nenhuma & 1 & $\mathrm{CD}$ & Só \\
\hline $\begin{array}{l}\text { Bartolo- } \\
\text { meu }\end{array}$ & 86 & $\begin{array}{l}\text { Ho- } \\
\text { mem }\end{array}$ & Viúvo & $3^{\mathrm{a}}$ Série & 2 & $\mathrm{CD}$ & $\begin{array}{l}\text { Com as filhas, } \\
\text { genros e netos }\end{array}$ \\
\hline Betânia & 93 & Mulher & Viúva & $3^{a}$ Série & 4 & $\mathrm{CD}$ & Com o genro \\
\hline
\end{tabular}

Quadro 3: Perfil dos/as participantes do Botão. 
Este é um território rural muito próximo ao centro da cidade (cujo acesso é facultado por transportes públicos - ônibus e trem - de relativa frequência), caracterizado por ser uma comunidade pequena, marcada pela entreajuda, com a igreja e o centro de dia como pontos centrais de convívio e interação social, inclusive intergeracional. Embora grande parte da população pertença a extratos sociais populares, a maioria reside em casas próprias, ainda que simples. A produção agrícola, em geral familiar, garante a não escassez de alimentos.

Finalmente, no Casal do Lobo, contei com a participação de dez pessoas: cinco mulheres e cinco homens com idades entre os 65 e os 79 anos, conforme o quadro que segue:

\begin{tabular}{|c|c|c|c|c|c|c|c|}
\hline NOME & $\begin{array}{l}\text { IDA- } \\
\text { DE }\end{array}$ & SEXO & $\begin{array}{c}\text { EST. } \\
\text { CI- } \\
\text { VIL }\end{array}$ & $\begin{array}{l}\text { ESCOLARI- } \\
\text { DADE }\end{array}$ & $\begin{array}{l}\text { FIL- } \\
\text { HOS }\end{array}$ & $\underset{\text { ATL }^{16}}{\text { CD/SAD/ }}$ & $\begin{array}{c}\text { COM QUEM } \\
\text { VIVE }\end{array}$ \\
\hline Camila & 65 & $\begin{array}{c}\text { Mul- } \\
\text { her }\end{array}$ & $\begin{array}{c}\text { Casa- } \\
\text { da }\end{array}$ & $4^{a}$ Série & $\begin{array}{l}3 \text { (1 fa- } \\
\text { lecido) }\end{array}$ & ATL & Com o marido \\
\hline $\begin{array}{c}\text { Cláu- } \\
\text { dio }\end{array}$ & 65 & $\begin{array}{l}\text { Ho- } \\
\text { mem }\end{array}$ & $\begin{array}{c}\text { Casa- } \\
\text { do }\end{array}$ & $4^{\mathrm{a}}$ Série & 2 & ATL & $\begin{array}{l}\text { Com a esposa } \\
2 \text { filhas, o } \\
\text { genro e } 1 \text { neto }\end{array}$ \\
\hline $\begin{array}{l}\text { Catari- } \\
\text { na }\end{array}$ & 66 & $\begin{array}{l}\text { Mul- } \\
\text { her }\end{array}$ & $\begin{array}{c}\text { Casa- } \\
\text { da }\end{array}$ & $4^{\mathrm{a}}$ Série & $\begin{array}{l}2 \text { (1 fa- } \\
\text { lecido) }\end{array}$ & ATL & $\begin{array}{l}\text { Com o marido } \\
\text { e } 1 \text { neto }\end{array}$ \\
\hline César & 67 & $\begin{array}{l}\text { Ho- } \\
\text { mem }\end{array}$ & $\begin{array}{c}\text { Casa- } \\
\text { do }\end{array}$ & $4^{\mathrm{a}}$ Série & $\begin{array}{l}3 \text { ( } 1 \text { fa- } \\
\text { lecido })\end{array}$ & ATL & Com a esposa \\
\hline $\begin{array}{c}\text { Cristi- } \\
\text { na }\end{array}$ & 68 & $\begin{array}{l}\text { Mul- } \\
\text { her }\end{array}$ & $\begin{array}{c}\text { Casa- } \\
\text { da }\end{array}$ & $3^{\mathrm{a}}$ Série & 3 & - & Com o marido \\
\hline Cássio & 68 & $\begin{array}{c}\text { Ho- } \\
\text { mem }\end{array}$ & $\begin{array}{c}\text { Casa- } \\
\text { do }\end{array}$ & $4^{a}$ Série & 3 & - & Com a esposa \\
\hline Cecília & 70 & $\begin{array}{l}\text { Mul- } \\
\text { her }\end{array}$ & $\begin{array}{c}\text { Casa- } \\
\mathrm{da}\end{array}$ & $3^{\mathrm{a}}$ Série & 3 & ATL & Com o marido \\
\hline Cora & 79 & $\begin{array}{c}\text { Mul- } \\
\text { her }\end{array}$ & $\begin{array}{c}\text { Casa- } \\
\text { da }\end{array}$ & $4^{\mathrm{a}}$ Série & 1 & $\mathrm{CD}$ & $\begin{array}{l}\text { Com o ma- } \\
\text { rido, a filha, } \\
\text { o genro e } 2 \\
\text { netos }\end{array}$ \\
\hline Cícero & 79 & $\begin{array}{l}\text { Ho- } \\
\text { mem }\end{array}$ & $\begin{array}{c}\text { Casa- } \\
\text { do }\end{array}$ & $4^{a}$ Série & 1 & $\mathrm{CD}$ & $\begin{array}{l}\text { Com a esposa } \\
\text { a filha, o gen- } \\
\text { ro e } 2 \text { netos }\end{array}$ \\
\hline $\begin{array}{c}\text { Caeta- } \\
\text { no }\end{array}$ & 79 & $\begin{array}{l}\text { Ho- } \\
\text { mem }\end{array}$ & $\begin{array}{c}\text { Casa- } \\
\text { do }\end{array}$ & $4^{\mathrm{a}}$ Série & 2 & ATL & Com a esposa \\
\hline
\end{tabular}

Quadro 4: Perfil dos/as participantes do Casal do Lobo.

De todos os/as participantes, os/as deste território são os/as mais jovens, nenhum/a vivendo sozinho. Tal como o que acontece no Botão, esta é uma pequena comunidade, onde quase todos os mem16 ATL: Atividades de Tempos Livres. 
bros apresentam algum grau de parentesco entre si. Com poucas crianças e jovens (os poucos têm sua vida ativa no centro da cidade), alguns equipamentos sociais têm suas funções modificadas. A escola, por exemplo, abriga, atualmente, uma instituição de atividades de tempos livres, com a oferta de oficinas (informática, trabalhos manuais) ao/às seus/as moradores/as, grande parte idosos/as. Além da igreja, o café deste território desempenha a função de centro comunitário e de convívio intergeracional.

Os contatos e entrevistas foram realizados em diferentes cenários destes quatro territórios, desde cafés e centros de dia, até as suas próprias residências. Nas interações realizadas nos $\mathrm{CD}$, pude perceber o entrosamento entre uns/umas, e também alguns conflitos entre outros/as. Nas entrevistas realizadas nas moradias, pude interagir melhor com as pessoas.

Minhas visitas aos quatro territórios, minhas interações com as pessoas que aceitaram participar do estudo, suas narrativas, suas expressões, fizeram-me acreditar que a qualificação dos territórios e, principalmente, das relações que se estabelecem entre seus sujeitos, incluindo aí os sujeitos idosos, deve passar necessariamente pelo cuidado. A escassez de cuidado foi observada, ainda que de formas diferentes, nos quatro territórios, indo desde a falta de acessibilidade de alguns territórios, até a fragilidade dos laços sociais estabelecidos em outros, passando pela negligência e o pouco envolvimento cuidadoso e afetivo no atendimento ao público idoso em alguns espaços como os centros de dia ou as próprias famílias.

Em minhas vivências com as pessoas idosas que participaram deste trabalho, foi possível perceber que o convívio e o estabelecimento de confiança são processos cotidianos, construídos através de relações sociais equilibradas e desierarquizadas, pautadas pela escuta, atenção e respeito mútuos. Sendo uma necessidade comum às pessoas idosas entrevistadas, mesmo as que frequentam um $\mathrm{CD}$ e, portanto, supostamente, têm aumentadas as oportunidades de conviver e desabafar com outras pessoas de sua ou de outra geração, a questão que se coloca é: por que esta necessidade é tão frequente? Através das entrevistas, pude constatar que, em alguns prováveis 
Territórios de cuidado: reflexões sobre a ética e a prática do cuidado na velhice.

contextos de sociabilidade, a escuta, a atenção, o respeito e o equilíbrio relacional - essenciais a uma ética e a uma prática do cuidado - são elementos escassos. Em outras palavras: estar na presença de outras pessoas, mesmo quando existem pequenas cordialidades e civilidades cotidianas, não é, necessariamente, sinônimo de sociabilidade. Sendo ainda mais explícita: frequentar um CD, um café, um parque ou uma praça; receber atendimentos de um SAD; ou mesmo estar presente numa reunião familiar não garante, por si só, relações de sociabilidade e de cuidado.

Algumas vozes ${ }^{17}$ recolhidas durante a investigação ilustram minhas percepções:

Sobre as relações familiares e vicinais:

Olha, sinto-me com mais saudades de meus queridos filhos! Não moram cá em Coimbra. Moram retirados. [À exceção de um dos filhos, que mora no municipio de Figueira da Foz, a cerca de 60 $\mathrm{km}$ de distância de Coimbra, os demais vivem em outras freguesias urbanas de Coimbra: a filha em Santa Clara e o filho em Eiras.] Mas não sou abandonada! O que é minha vontade era ir viver com um deles. Mas a casa da minha filha é pequenina. Pronto. Vive em Santa Clara, ao pé da Rainha Santa. A casa é dela. Tem um filho formado, também - ali a fotografia dele. Pronto. Tenho o engenheiro-este é que está bem. E é que me podia ajudar... [Vive] em Eiras. E este que podia ajudar-me, dar assim uma ajuda, porque a mulher... mas foram lhe dizer que eu disse mal da mulher. A mulher é formada, é assistente social, ela. E ela confiou... E gosto muito dela! O outro vive na Figueira. Longe. Está desempregado há cinco anos. Também andava a estudar. Foi pra Alemanha, que a mulher dele é alemã. (Dona Anita, 86 anos, Alta)

Conheço, conheço os do primeiro andar, que já cá vivem há muito tempo. Os do segundo e terceiro as casas são alugadas a estudantes ou pessoas que vêm de fora e eu não faço ideia nenhuma quem é que lá está. Eles cumprimentam quando passam, e eu vejo pessoas diferentes e não fico a saber quem é. (Dona Sara, 76 anos, Solum)

Sobre a autonomia:

Agora já não acho nada porque agora daqui é só para o cemitério.

$17 \mathrm{O}$ material recolhido durante o estudo é bastante extenso e rico. Para este artigo, escolhi algumas falas que, julgo, podem dar uma ideia de meu embasamento empírico.

$\mathbf{8 4 0} \mid$ Século XXI, Revista de Ciências Sociais, v.9, nº 3, Ed. Especial, p.820-853, 2019 
Daqui é para o cemitério. Oh... que remédio tenho eu! [respondendo à questão sobre o que acha da casa onde vive].(Dona Amanda, 87 anos, Alta)

Se elas quiserem me dar hoje [banho], é hoje; se não quiser, dão amanhã. Eu até já trouxe a roupa.(Dona Betânia, 93 anos, Botão)

Em Pereira [no hospital] estive quatro horas à espera [para ir ao banheiro]. Quatro horas. Eu chamei um rapaz que lá havia-que havia lá rapazes que nos lavavam. E um dia ele lavava-me e eu disse: "eu queria ir fazer xixi". E ele vai assim: "eu venho já". E ali havia muitas que não podiam vir cá comer à baixa, comiam lá em cima, nos quartos. Os quartos eram, assim, uma bagunça. E depois, ele vai assim: "eu venho já", e eu: "quero ir fazer xixi”, "faça na fralda", e eu assim: "vou agora fazer xixi na fralda, não tou habituada a isso, não sou capaz”, e depois, esperei, esperei e ele foi lá ao fim da tarde, um bocado... isto foi ao fim do almoço. E depois: "você já há uma hora que eu lhe pedi pra fazer xixi e eu perdi a paciência", "espera um bocadinho que me chamaram pra ir dar o lanche. Ai o tempo foi passando, passando, passando, eu fui obrigada a fazer na fralda mesmo, já não me aguentei mais. Disse "sim, agora por sua causa tive que fazer na fralda", "ai desculpe, mas eu não pude, não sei o que", "tá bem”. Em primeiro lugar estava a gente. Os do café podiam esperar um bocadinho.(Dona Bárbara, 85 anos, Botão)

Dantes, gostava de ir nos passeios. Agora, já não mais. Mas vou, na mesma.(Senhor Lino, 86 anos, Botão)

\section{Sobre a acessibilidade e mobilidade:}

Como vinha quase boa do hospital, vinha toda contente. Do hospital vinha, mas nesta rua, uma vez dei uma queda logo à entrada da porta. Esta rua, eu não sou capaz de a descer nem de a subir. Já são três vezes que eu caio aí nesta rua. (Dona Aurora, 89 anos, Alta)

Já, caí muita vez. E quando eu andava a trabalhar, uma vez dei lá uma queda, ia com a caixa do dinheiro... e espalhou o dinheiro, espalhou tudo! (Dona Adelaide, 74 anos, Alta) 
Territórios de cuidado: reflexões sobre a ética e a prática do cuidado na velhice.

Em casa às vezes dá-se um tombo sem querer. Até tropeçar nos tapetes. Na rua... já cai no meu quintal. Pronto. É assim. Diz que quem vai à água, sempre se molha, não é? É natural. Então, quando a gente começa a ter uma certa idade, já não tem aquele equilíbrio que devia ter e a gente cai com facilidade. Um dia desses, lá em casa, estava vestindo as calças e não sei porque eu caí. Eu cambaleei, agarrei-me à cama, caí pra cima do tapete. (Senhor Sérgio, 84 anos, Solum)

Uma parte significativa da literatura científica - das áreas da saúde, educação e mesmo das ciências sociais - a respeito do cuidado, toma-o como uma relação vertical e hierárquica, algumas enfatizando os aspectos econômicos desta relação, numa clara visão marxista que deve ser complementada por aspectos mais subjetivos, mas também fundamentais nas relações sociais, como a afetividade e a interdependência, por exemplo. Embora não desconheça a importância dos referidos estudos e do viés por eles abordados, creio que, mesmo sem ser esta sua intenção, muitas vezes acabam por contribuir na cristalização de preconceitos em relação à dependência $\mathrm{e}$ vulnerabilidade, penalizando os sujeitos velhos, homogeneizados a partir de fraquezas e dependências que, em verdade, dizem respeito à própria condição humana, não sendo privilégio das pessoas idosas.

A ênfase dada ao cuidado técnico, por assim dizer, com a priorização de uma atenção voltada aos aspectos mais físicos do cuidado (higiene pessoal e ambiental e alimentação, por exemplo), separando-os de seus aspectos mais subjetivos, muitas vezes neglicenciados (mas cuja negligência é, em geral, menos perceptível), além de uma extrema responsabilização sobre a família e os/as profissionais de cuidado (enfermeiros/as, técnicos/as, assistentes sociais) em detrimento de uma visão mais abrangente, filosófica e paradigmática do cuidado, parece ter como resultado a desresponsabilização dos governos e da sociedade civil, como um todo, pelo cuidado, além de ser visivelmente limitadora de uma maior qualidade de vida, de um modo geral, mas principalmente no que diz respeito ao afeto, ao convívio, à participação, à autonomia e ao protagonismo social dos sujeitos idosos. Muitas famílias e demais redes sociais, inclusive redes de apoio, como os Centros de Dia, ou os Serviços de Apoio 
Domiciliário, ou mesmo os Lares para idosos/as, não se dão conta da tenuidade entre abandono, negligência e falta de cuidado e atenção. $\mathrm{O}$ que se percebe, em muitas das vezes, é a prestação, às pessoas idosas, de serviços básicos, como higiene e alimentação. Estes são serviços essenciais e necessários que, realmente, não podem ser negligenciados. Entretanto, estão longe de se configurarem como núcleo primordial da atenção e do cuidado.

Sobre este aspecto, destaco os cuidados prestados pelos CD e os SAD no atendimento aos/às idosos/as. Estas instituições parecem minimizar a fragilidade social de alguns/as idosos/as, já que propiciam o convívio diário entre pessoas idosas e destas pessoas com os/as prestadores de serviços (assistentes sociais, funcionários/ as, atendentes). Entretanto, a prioridade a uma atenção primária com ênfase à alimentação e à higiene, bem como a falta de uma atenção multiprofissional e de um planejamento pedagógico que realmente propicie a sociabilização e a interação das pessoas idosas, principalmente as frequentadoras dos CDs, mas também as que recebem atendimento dos SAD, contemplando suas necessidades e interesses e desenvolvendo suas habilidades físicas, mentais, psicológicas e sociais, acabam por esvaziar os cotidianos destas pessoas de sentido, homogeneizando-as, inviabilizando qualquer projeto de vida e enfraquecendo sua autonomia, suas identidades e seus laços sociais.

Outra questão que, assim me parece, deve ser problematizada concerne ao sexo/gênero nas relações de cuidado. As entrevistas possibilitaram-me a comprovação de que, na maioria das vezes, quem cuida é a mulher, tanto nas instituições de cuidado, quanto na família e mesmo na vizinhança. Mesmo em casos de haver mais de um homem cohabitando a mesma casa, sem a presença constante de uma mulher, o cuidado doméstico e mesmo o apoio à realização de tarefas como higiene pessoal e idas ao banco, por exemplo, eram quase sempre realizados por uma representante deste sexo (membro da família, empregada doméstica, vizinha).

Eu moro sozinho. A minha filha anda a trabalhar desde de manhãe à noite vai ter comigo. Mora ali em cima. Ela mora ali em cima, eu moro mesmo aqui. É ela, ela [quem limpa a casa]. É ela, e ela que 
Territórios de cuidado: reflexões sobre a ética e a prática do cuidado na velhice.

me dá o pequeno-almoço [café da manhã, no português brasileiro] de manhã. Antes de ir para o serviço dá-me o pequeno-almoço sempre. (Senhor Bento, 85 anos, Botão)

Lá em casa só vive o meu cunhado - infelizmente a mulher morreu - e... e um filho, um filho. Desde que morreu-me esta, esta minha irmã, esta, a minha... Depois que ela morreu, nunca mais, nunca mais, nunca mais liguei o rádio. Não dá vontade. A pessoa fica, fica... Fiquei, fiquei de uma maneira... Minha sobrinha vive cá perto. Ela que cuida da casa, da roupa, do comer... (Senhor Bernardo, 79 anos, Botão)

Também pude perceber que são poucas as discussões acadêmicas que propõem o cuidado enquanto um princípio ético. Ao observar territórios inóspitos e até hostis, em termos de acessibilidade e mobilidade; pessoas idosas tendo sua autonomia negligenciada; o desrespeito, a falta de consideração e afeto pelas pessoas mais velhas, sua solidão e isolamento em alguns territórios, percebi o quanto nossas sociedades, territórios e relações sociais carecem de cuidado.

Assim, após a análise dos dados coletados, destaco como tese a defesa de uma proposta de mudança paradigmática a partir de relações cotidianas alicerçadas pelo cuidado. Para isso, apresentarei, a seguir, algumas sugestões e proposições para que estes preceitos éticos possam ser efetivados nas práticas cotidianas. As propostas aqui elaboradas não têm a intenção - nem o alcance - de solucionar as demandas percebidas nos territórios estudados. Devem, antes, ser interpretadas como um impulso, um estímulo, um ponto de partida para a construção coletiva, e em permanente diálogo e dialética de ação-reflexão-ação, de novas e melhores práticas e posturas, públicas, coletivas e individuais, sempre em consonância ao princípio ético do cuidado.

Embora reconheça o papel das instituições e dos gestores públicos na qualificação dos territórios - a partir de práticas e políticas voltadas para sua população -, destaco aqui a importância da educação - formal, informal e não formal - no desenvolvimento de um ethos e de uma práxis que tenham o cuidado como propósito e também como meio. Isso não significa desresponsabilizar os demais 
agentes. Pelo contrário, estas reflexões buscam ir ao encontro da responsabilização de todos/as por todos/as, num movimento que se quer crescente e abrangente; que, nas dificuldades de uma simultaneidade, comece nos territórios de proximidade, mas que, aos poucos, vá se espalhando por seu entorno. São, aliás, nos territórios de proximidade que as identidades são fortalecidas, construídas e reconstruídas nas relações cotidianas.

\title{
TERRITÓRIOS DE CUIDADO - PROPOSIÇÕES
}

\begin{abstract}
"Em primeiro lugar a ética do cuidado faz apelo à responsabilidade e a relações mais do que a direitos e normas. Depois, uma tal ética está mais ligada às circunstâncias concretas do que aos aspectos formais e abstractos. Finalmente a ética do cuidado é expressa adequadamente não tanto por um conjunto de princípios mas por uma actividade, 'a actividade do cuidado"' (Pintasilgo, 2012, p. 139).
\end{abstract}

O estudo realizado permitiu considerar que o enfrentamento dos problemas vividos por muitas pessoas idosas, relatados em muitas de suas falas, principalmente em relação às possibilidades de sociabilidade, mas também incluindo as dificuldades de acesso e acessibilidade a bens e serviços e à própria participação e protagonismo nos territórios, e ainda as muitas limitações em termos de mobilidade, passa por um comprometimento ético dos diversos atores nas mais variadas instâncias sociais.

Como, entretanto, desenvolver a "atividade do cuidado", indicada por Pintassilgo (2012), de modo que, pouco a pouco, nossas relações sejam pautadas e desenvolvidas dentro do princípio ético do cuidado? De aproximadamente trinta anos para cá, muitos estudos antropológicos e sociológicos, por todo o mundo, têm se dedicado à temática do cuidado. Penso, no entanto, que ainda faltam reflexões que, por um lado, abordem o cuidado como um princípio axiológico mais amplo, e, por outro, sejam mais propositivas.

Elencando os principais problemas da população idosa nos (e dos próprios) territórios, creio que o destaque maior pode ser dado para as dificuldades de mobilidade de grande parte das pes- 
soas pesquisadas, acentuando-se nos territórios com acessibilidades deficientes - principalmente a Alta, neste caso, mas também os territórios rurais do estudo -; pouca frequência e/ou qualidade dos processos de sociabilidade (mais uma vez, acentuadas em territórios pouco acessíveis e com relações altamente hierarquizadas como, novamente, a Alta de Coimbra), resultante de poucas oportunidades de estabelecimento de interações e convívios mais profundos e significativos; baixa autonomia de algumas pessoas em relação a escolhas cotidianas, que dizem respeito à gestão de suas próprias vidas (notadamente nas pessoas que frequentavam os centros de dia ou faziam uso dos apoios domiciliares); aumento da dependência para realização de tarefas diárias, dependência, esta, confundida com vulnerabilidade e interferindo diretamente na autonomia destes sujeitos.

Dessa forma, é possível considerar que a qualificação das experiências de velhice deve passar, necessariamente, pela qualificação dos próprios territórios. Esta qualificação, por sua vez, só pode se concretizar através do desenvolvimento de uma ética e de uma práxis que tenha o cuidado como princípio (filosófico), meio (estratégico) e fim (finalidade).

A criação e o desenvolvimento destes territórios - os territórios de cuidado - passam, necessariamente, pela educação integral e contínua ao longo da vida. Daí a relevância das relações sociais, tanto no âmbito da educação formal, não formal e informal, e, quando se fala especificamente em educação formal, das instituições educativas: as escolas, em seus vários níveis, e as universidades.

Assim, estes territórios de cuidado, acessíveis, e onde as pessoas - todas, incluindo as idosas - podem se movimentar com segurança e construir sociabilidades consistentes, alicerçadas na igualdade, no respeito às diferenças e às pluralidades, no afeto e no compromisso mútuos, são também, eles próprios, essenciais para a constante qualificação dos territórios - compreendidos em sua multidimensionalidade relacional - e das experiências de velhice. São, também, um direito e uma responsabilidade de todos/as.

Em primeiro lugar, territórios de cuidado precisam ser fisicamente acessíveis a todas as pessoas, facilitando a mobilidade e possibilitando o desenvolvimento de um sentimento de pertença- 
e, consequentemente, de responsabilidade - ao território. Na Alta, por exemplo, o território mais crítico do estudo neste sentido, são necessárias adaptações ao longo de todo o território: instalação de corrimãos nas escadarias; colocação de piso aderente/antiderrapante nas escadarias e vias de uso pedestre, de modo a torná-las mais niveladas, evitando, assim, as quedas e os escorregões; e, quando possível, instalação de rampas de acesso. Estas mudanças pequenas, de custos pouco elevados e com poucos abalos ao patrimônio histórico podem representar um enorme ganho à população residente e mesmo um impulso ao turismo, com a acessibilização do território. Sobre este último aspecto, aliás, é necessário que os gestores públicos estabeleçam um diálogo sério e responsável com a população residente deste território, buscando estratégias de adequação entre a preservação patrimonial e a qualidade de vida de seus/as moradores/ as e, por extensão, dos/as próprios/as turistas.

A acessibilidade, entretanto, não diz respeito somente aos acessos (físicos) a um determinado território. Ela "deve ser discutida em suas dimensões materiais e imateriais, já que a garantia de acesso físico a determinados espaços urbanos não garante sua apropriação simbólica" (Serpa, 2016, p. 171). A falta de domínio de um determinado "repertório" (Certeau, 1998) ou de um "capital escolar ou cultural" (Bourdieu, 2007) impede, muitas vezes, a apropriação ou a acessibilidade de pessoas e grupos a determinados territórios.

No que tange à qualificação física dos territórios, estas sugestões se estendem, de forma semelhante, às demais localidades. No Botão e no Casal do Lobo, por exemplo, as vias também carecem de melhorias, principalmente em relação às suas redes pedonais - quase inexistentes.

As valas para escoamento da água da chuva, existentes na quase totalidade da via principal do Botão, por exemplo, precisam ser cobertas para que os riscos eminentes sejam evitados. Em vias de trânsito mais intenso, como são as vias principais do Botão e do Casal do Lobo, que dão acesso a outras localidades, é necessária a delimitação de um espaço de uso exclusivo para pedestres.

Tanto os territórios da Alta, como do Botão e do Casal do Lobo, deparam-se com uma sinalização bastante deficiente. Nos três 
territórios, é necessária a instalação de sinais que esclareçam a velocidade máxima permitida ao trânsito de automóveis e, sendo muitos dos espaços compartilhados, a hierarquia a ser respeitada, do mais ao menos vulnerável: cadeirantes, pedestres, carrinhos de bebês, bicicletas, motocicletas e automóveis. A fiscalização, por parte dos órgãos de trânsito responsáveis, também deve ser uma prioridade a ser cumprida. Na Alta, mais uma vez, o desrespeito dos automóveis em relação aos pedestres é flagrante: carros estacionados nas calçadas quando estas existem - são um claro exemplo da vulnerabilização a que os pedestres estão sujeitos. Para diminuir o afluxo de automóveis neste território que, em razão da Universidade e de ser um ponto turístico, acaba por conviver diariamente com este problema, é necessário o desenvolvimento de políticas de mobilidade adequadas, construídas com a participação comunitária.

No caso da Solum, o problema maior parece ser a alta velocidade com que os automóveis trafegam, apesar de este território estar bem equipado com semáforos e faixas de segurança. A este respeito, algumas providências práticas podem ser tomadas: instalação de redutores de velocidade e de sinalética adequada, informando a velocidade máxima permitida em um território que, além de comércios e serviços, comporta um grande número de residências. Em vias mais largas e movimentadas, os semáforos devem permanecer por mais tempo acesos no sinal vermelho destinado aos automóveis, e no verde, destinado aos pedestres, permitindo a travessia mais segura de pessoas com mobilidade reduzida.

Além disso, a promoção de uma ética do cuidado passa, prioritariamente, pela responsabilidade da educação - em todos os seus níveis e instâncias -, através da produção teórica reflexiva constante, mas, principalmente, através do desenvolvimento de práticas que tenham o cuidado como princípio, meio e fim de todo e qualquer processo educativo/relacional.

Em termos de educação formal, por exemplo, é necessário que as escolas se abram à diversidade de saberes e ideias, se abrindo, também, a toda a comunidade, buscando uma integração geracional, étnica e de gênero nas suas relações cotidianas. Ao priorizar a construção coletiva dos conhecimentos, bem como a valorização de 
conhecimentos produzidos no exterior da escola, por outros agentes educativos, que não os/as professores/as (pais/mães, avós, pessoas do território onde está inserida a escola, por exemplo), a escola estará promovendo uma pedagogia do cuidado. É importante destacar que este também é um papel das instituições de ensino superior principalmente as públicas, mas também as privadas - e não só das escolas de educação básica, como se tem naturalizado ao longo da história da educação formal. As universidades e faculdades, através de seus variados cursos e níveis têm muito a contribuir, não só com pesquisas, mas também na formação de professores/as e, mais especificamente, através do envolvimento de seus/as estudantes/as na promoção e consolidação de relações intergeracionais ricas e produtivas.

A criação e manutenção de espaços de convivência intergeracional - praças, centros públicos de convívio e de eventos - devem ser de responsabilidade do poder público municipal, que pode propor parcerias com outras instâncias públicas e mesmo com a iniciativa privada.

As relações intergeracionais, por sua vez, devem ser promovidas e estimuladas a partir do que Ferrigno (2003) denomina de "co-educação entre gerações". Este é um processo que deve se desenvolver cotidianamente, com as diferentes gerações partilhando experiências, ensinando e aprendendo, buscando superar preconceitos mútuos, numa abertura ao novo e à diversidade. É importante destacar que este convívio respeitoso e horizontal entre as gerações deve ser aprendido, a partir de esforços de todos/as, onde os conflitos, antes de serem evitados, devem ser aproveitados como novas oportunidades de aprendizagem.

Construir uma ética do cuidado passa, então, pela "rediscussão da responsabilidade dos indivíduos - pela própria vida e pela dos outros -, assim como a reflexão sobre a responsabilidade social pela dependência" (Biroli, 2014, p. 58), esta última entendida como condição humana (Boff, 1999; 2005; 2006).

Como toda a construção ética tem seu alicerce no campo da prática (Barbosa, 2009), pequenas mudanças nas relações cotidianas - as "revoluções moleculares" mencionadas por Guattari (1992, p. 
$175)^{18}$ - podem começar a partir de unidades territoriais menores, $\mathrm{o}$ que não impede a simultaneidade de ações, práticas e políticas nos diversos âmbitos territoriais.

Finalmente, a desmistificação da dependência como algo negativo e unilateral é um passo extremamente importante na direção dessa práxis. Reconhecer que todas as pessoas, independente de idade, classe social, gênero e etnia são seres vulneráveis, dependentes de cuidado, é também reconhecer as pessoas idosas em sua integridade, enquanto pessoas dignas de respeito e atenção, tal como todas as demais. Este é um desafio constante, que exige esforços individuais e coletivos. Exige que se abra mão de certezas já instituídas, de padrões já estabelecidos. Exige que se abra duplamente: de si para si; e de si para o(s)/a(s) outro(s)/a(s).

\section{REFERÊNCIAS}

ARENDT, H. O que é política? 12a ed., Rio de Janeiro: Bertrand Brasil, 2018 [1950].

BARBOSA, V. Da Ética da Libertação à Ética do Cuidado: uma leitura a partir do pensamento de Leonardo Boff. São Paulo: Porto de Ideias, 2009.

BATALLER, M. A. S. O estudo da gentrificação. Revista Continentes, ano 1, n. 1. Rio de Janeiro: Universidade Federal do Rio de Janeiro, 2012. pp. 09-37.

BIROLI, F. Justiça e Família. In: BIROLI, F.; MIGUEL, L.F. Feminismo e Política. Rio de Janeiro, RJ: Boitempo Editorial, 2014. pp. 47-63.

BOFF, L. Saber cuidar - Ética do humano - compaixão pela Terra. Petrópolis: Editora Vozes, 1999. Disponível em: http://www.vozes. com.br. Acesso em 15/12/2015.

BOFF, L. O cuidado essencial: princípio de um novo ethos. Revista Inclusão Social, Brasília v. 1, n. 1, out./mar., 2005, pp. 28-35.

BOFF, L. A força da ternura. Rio de Janeiro: Sextante, 2006.

BOURDIEU, P. A distinção: crítica social do julgamento. São Paulo: EDUSP; Porto Alegre: Zouk, 2007.

18 Para Guattari (1992, p. 175), as "revoluções moleculares" contribuem para as mudanças de mentalidades. Ao mesmo tempo, as possibilidades de tais mudanças são dadas a partir de um movimento de transformação global das sociedades. 
CARVALHO, M. R. de; MAIA, M. S. Em tempos de descuido: o paradigma do cuidado. In: MAIA, M. S. (Org.). Por uma ética do cuidado. Rio de Janeiro: Garamond, 2009. pp. 19-25.

CERTEAU, M. de. A invenção do cotidiano - Artes de fazer. $3^{\mathrm{a}}$ ed. Petrópolis: Editora Vozes, 1998.

FERRIGNO, J. C. Co-educação entre gerações. Petrópolis: Vozes, 2003.

FISHER, B.; TRONTO, J. Toward a feminist theory of caring. In: ABEL, E. K.; NELSON, M. K. (Eds.). Circles of Care - Work and identity in women's lives. Albany, NY: State University of New York Press, 1990. pp. 36-54.

FRASER, N. Da redistribuição ao reconhecimento? Dilemas da justiça numa era "pós-socialista". Cadernos de Campo. São Paulo, 2006, n. 14/15, pp. 231-239. Tradução de Júlio Assis Simões.

FRASER, N. Reconhecimento sem ética?. Lua Nova. São Paulo, 2007, n. 70, pp. 101-138.

FREIRE, P. Pedagogia da autonomia: saberes necessários à prática educativa. São Paulo: Paz e Terra, 1997.

GALEANO, E. Patas arriba. La escuela del mundo al revés. $7^{\circ}$ ed. Cidade do México: Siglo XXI Editores, 2004.

GILLIGAN, C. In a different voice. Psychological Theory and women's development. Cambridge, Massachussets and London: Harvard University Press, 1993.

GUATTARI, F. Caosmose - Um novo paradigma estético. Tradução de Ana Lúcia de Oliveira e Lúcia Cláudia Leão. São Paulo: Editora 34, 1992.

HEIDEGGER, M. Ser e Tempo - Parte I. Tradução de Márcia de Sá Cavalcante. Petrópolis: Editora Vozes, 1989.

KUHNEN, T. A. A ética do cuidado como teoria feminista. Anais do III Simpósio Gênero e Politicas Públicas. Londrina: Universidade Estadual de Londrina, 2014. pp. 1-9.

KUHNEN, T. A. Epistemologia feminista e a reconfiguração da filosofia moral. Sapere Aude. Belo Horizonte, v. 5, n. 9, $1^{\circ}$ sem/2014, 2014 b. pp. 196-219.

LOBO, M. da C.; SIMÕES JÚNIOR, J. G. Introdução. In: LOBO, M. da C.; SIMÕES JÚNIOR, J. G. (Orgs.). Urbanismo de colina - Uma tradição luso-brasileira. São Paulo: Universidade Presbiteriana Mackenzie, 2012. pp. 15-43.

MOZÈRE, L. Avant-propos. In: TRONTO, J. Un monde vulnérable - pour 
Territórios de cuidado: reflexões sobre a ética e a prática do cuidado na velhice.

une politique du care. Paris: Éditions La Découverte, 2009. pp. 5-10.

MURARO, R. M. História do masculino e do feminino. Rio de Janeiro: Zit, 2007.

NUNES, L. Ética no fim da vida - E quando eu não puder decidir?. Lisboa: Fundação Francisco Manuel dos Santos, 2016.

PALACIO, N. M. D. La ética del cuidado: una voz diferente. Revista Fundación Universitaria Luis Amigó. Medellín, vol. 2, n. 1, janjun/2015, pp. 12-21.

PEREIRA, R. R. A importância da concepção de sujeito implícita na Ética do Cuidado. Winnicott e-Prints, vol. 6, n. 1, São Paulo, 2011. pp. 66-79.

PÉREZ, S. A. C. El cuidado como objetivo político-social, una nueva mirada desde la ética del cuidado. Anais do III Congreso Anual de La REPS - Red Española de Política Social. Pamplona, 2011. pp. $1-17$.

PINTASILGO, M.de L. Cuidar o futuro. In: PINTASILGO, M.de L. Para um novo paradigma: $\mathrm{O}$ mundo assente no cuidado - Antologia de Textos. Porto: Edições Afrontamento, 2012. pp. 127-139.

SAFFIOTI, H. I. B. Gênero, patriarcado, violência. São Paulo: Editora Fundação Perseu Abramo, 2007.

SCOTT, J.W. Gênero: uma categoria útil de análise histórica. Educação \& Realidade. Porto Alegre, vol. 20, n. 2, jul-dez/1995. pp. 71-99.

SERPA, A. Segregação, território e espaço público na cidade contemporânea. In: VASCONCELOS. P. de A.; CORREAA, R. L.; PINTAUDI, S. M. (Orgs.). A cidade contemporânea - Segregação espacial. São Paulo: Editora Contexto, 2016. pp. 169-188.

SIMÕES, J. F.; BRAZ, M.; GOUVEIA, P. H. de; BISPO, R.; LORENA, M. J. Uma casa para a vida - Aplicação do design inclusivo à habitação. Lisboa: Instituto Nacional para a Reabilitação, I.P., 2010.

SODRÉ, N. W. Tudo é politica: 50 anos do pensamento de Nelson Werneck Sodré em textos inéditos em livro e censurados. Rio de Janeiro: Mariachi, 1998.

SZPACENKOPF, M. I. O. Igualdade e reconhecimento: princípios para uma ética do cuidado. In: MAIA, M. S. (Org.). Por uma ética do cuidado. Rio de Janeiro: Garamond, 2009.

TRONTO, J. Un monde vulnérable - pour une politique du care. Paris: Éditions La Découverte, 2009. 
VEIGA, M. R. M. Velhices e territórios: Um estudo interdisciplinar no concelho de Coimbra, Portugal. 2017. 323 p. Tese (Doutoramento em Estudos Contemporâneos), Universidade de Coimbra, Instituto de Investigação Interdisciplinar, Centro de Estudos Interdisciplinares do Século XX, Coimbra, 2017.

ZATTI, V. Autonomia e Educação em Immanuel Kant e Paulo Freire. Porto Alegre, RS: EDIPUCRS, 2007. 